\title{
The Metabolism of Erythritol by Brucella abortus
}

\author{
By J. D. ANDERSON AND H. SMITH \\ Microbiological Research Establishment, Porton, Near Salisbury, Wiltshire
}

(Received 21 September 1964)

\section{SUMMARY}

The growth of a virulent strain of Brucella abortus was stimulated by low concentrations of erythritol in a medium containing high concentrations of glucose and a wide range of amino acids. During growth in this medium the organisms used about $1 \frac{1}{2}$ times their weight of erythritol as a carbon and energy source. The effect of erythritol was specific, since several $\mathrm{C}_{3}$ to $\mathrm{C}_{6}$ homologues had no growth-stimulating activity. Radiotracer studies showed that a large proportion of the carbon of the erythritol was excreted as carbon dioxide; that remaining in the organisms was fairly uniformly distributed over all components. Erythritol and 2-deoxy-2fluoro-DL-erythritol inhibited incorporation of glucose by the organism.

\section{INTRODUCTION}

In bovine brucellosis the preferential growth of Brucella abortus in certain foetal materials (placenta, chorion, the fluids) appeared to be due to the presence in these tissues of erythritol, a growth stimulant for $\boldsymbol{B}$. abortus which is absent from maternal tissues (Smith et al. 1962; Pearce et al. 1962; Williams, Keppie \& Smith, 1962). This polyol had already been shown to be the best of nine carbohydrates tested as a sole carbon source for the growth of Brucella in a simple medium (McCullough \& Beal, 1951). Further work showed that the course of brucellosis in other animal species might also be explained by the presence of erythritol in susceptible tissues (Keppie, Williams, Witt \& Smith, 1965). The importance of erythritol metabolism by $B$. abortus in animal infections prompted the present in vitro investigation and influenced the choice of experimental conditions. The effect of erythritol has been studied during the growth of a virulent strain (544) of $B$. abortus in a complex defined medium containing adequate carbohydrate in addition to erythritol. Kinetic and radiotracer studies soon showed that, despite the presence of an optimum amount of glucose, $B$. abortus used erythritol as a carbon and energy source. The growth-stimulating effect of small quantities of erythritol $(0.001 \mu \mathrm{mole} / \mathrm{ml}$.) previously reported (Smith et al. 1962; Pearce et al. 1962) had occurred because only correspondingly small populations were studied. Hence, the uptake and subsequent fate of erythritol have been investigated together with the influence of erythritol on glucose metabolism. This work was reported briefly elsewhere (Anderson \& Smith, 1963) and is complemented by parallel work on the effect of erythritol analogues on the growth of B. abortus (Smith et al. 1964). 


\section{METHODS}

Erythritol. Commercial erythritol was recrystallized from aqueous acetone to yield a chromatographically pure sample.

Organism. The virulent, $\mathrm{CO}_{2}$-dependent strain 544 of Brucella abortus was freezedried for storage. Cultures from the freeze-dried stock on slopes of tryptic meat $\operatorname{agar}\left(37^{\circ} ; 5 \% \mathrm{CO}_{2}\right.$ in air) were stored at $4^{\circ}$ for up to one month to provide seed. A subculture $\left(37^{\circ} ; 5 \% \mathrm{CO}_{2}\right.$ in air, overnight) on a tryptic meat agar slope was washed off with the defined medium (see below), centrifuged, resuspended in fresh defined medium and then grown overnight (shake culture; $37^{\circ} ; 5 \% \mathrm{CO}_{2}$ in air) to provide inoculum for the growth experiments.

Table 1. Composition of a defined medium for studies of the metabolism of erythritol by Brucella abortus

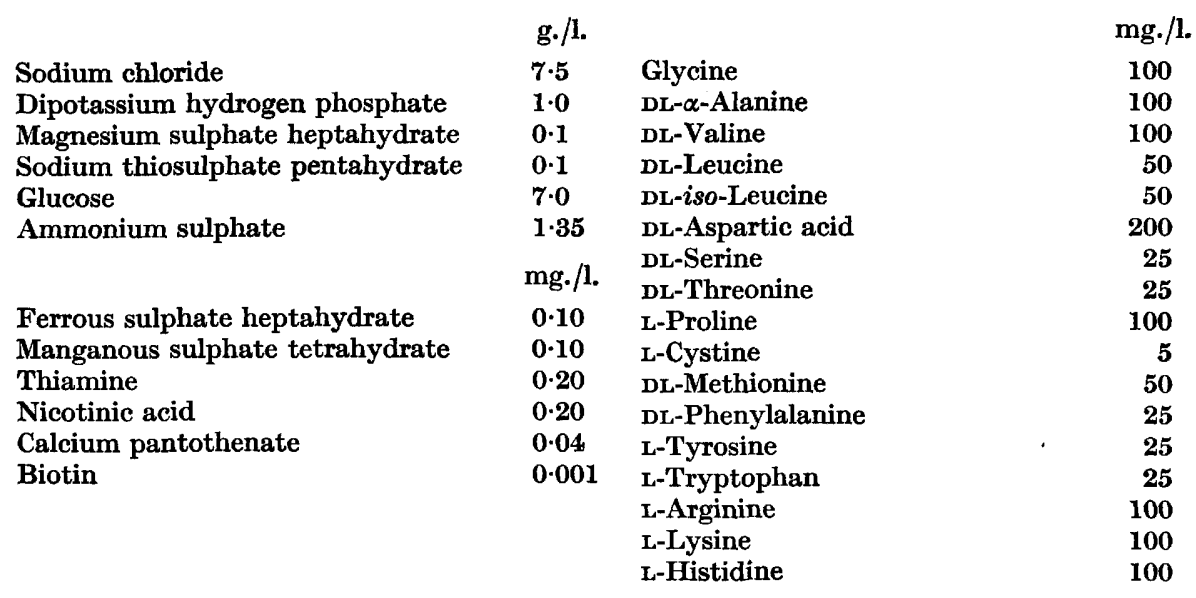

Adjusted (NaOH) to $\mathrm{pH} \mathrm{6.8} \mathrm{at} 37^{\circ}$.

Defined media. The medium shown in Table 1 is a modification of that of Rode, Oglesby \& Schuhardt (1950); the large glutamic acid component (3000 $\mu \mathrm{g} . / \mathrm{ml}$.) was replaced by ammonium sulphate and additional glucose. The stimulatory effect of erythritol could not be demonstrated in the original medium and, although smaller amounts of glutamic acid (10-1000 $\mu \mathrm{g} . / \mathrm{ml}$.) did not interfere with the erythritol effect, all glutamic acid was excluded from the medium. A stock medium $(4 \times$ strength, without biotin) was stored at $-\mathbf{2 5}^{\circ}$. When required, biotin was added to the diluted stock medium adjusted to $\mathrm{pH} 6 \cdot 8$, and the medium sterilized by filtration through a double layer of Oxoid membrane filter (Grade AP; Oxoid Ltd.) Any modifications of the chosen medium were stored and sterilized in a similar manner.

Growth of Brucella abortus in a liquid medium, with and without erythritol. Apparatus was washed successively in detergent, chromic + sulphuric acid, water, nitric acid and distilled water, then sterilized at $160^{\circ}$ for $2 \mathrm{hr}$. Inoculated medium $(4.9 \mathrm{ml}$.) and various concentrations of erythritol in Locke's solution $(0.1 \mathrm{ml}$.) were placed in flasks $(25 \mathrm{ml}$.) plugged with gauze-covered cottonwool. The flasks were shaken ( $5 \mathrm{~cm}$. throw, 100 oscillations $/ \mathrm{min}$.) at $37^{\circ}$ in gas-tight aluminium boxes filled with humidified $5 \% \mathrm{CO}_{2}$ in air. Flasks were removed for examination at intervals up to $60 \mathrm{hr}$. 
Growth occurred consistently from inocula of $2 \times 10^{7}$ bacteria $/ \mathrm{ml}$. or more but with small inocula $\left(1 \times 10^{4}\right.$ bacteria $/ \mathrm{ml}$.) erratic results were obtained unless gelatin (Simeon \& Co. Ltd, Luton; solution sterilized at $120^{\circ}$ for $15 \mathrm{~min}$.) was added to the medium (10 $\mu \mathrm{g} . / \mathrm{ml}$; ; see ZoBell \& Meyer, 1932).

Measurement of bacterial growth. Most bacterial populations were estimated by optical extinction measurements at $430 \mathrm{~m} \mu$ (Coleman spectrophotometer, Model 14, for populations greater than $1 \times 10^{8}$ bacteria/ml.; the Unicam (S.P. 500) spectrophotometer with the $4 \mathrm{~cm}$. cell for populations down to $2 \times 10^{7} \mathrm{bacteria} / \mathrm{ml}$.) after treatment with formalin $(3 \%, \mathrm{v} / \mathrm{v} ; 30 \mathrm{~min}$.). A linear relation between extinction readings and Helber chamber counts was obtained for the range $2 \times 10^{7}$ to $5 \times 10^{9}$ bacteria/ml. (statistical analysis by Mr S. Peto); and this relation, originally determined on cultures without erythritol, held for cultures of Brucella abortus grown with various concentrations of erythritol and examined before and after the erythritol had been depleted. Comparison of Helber chamber counts and viable counts (on tryptic meat agar-with $5 \%$ peptic sheep blood) showed the bacteria to be greater than $85 \%$ viable.

$2 \cdot 05 \times 10^{10}$ organisms weighed $1 \mathrm{mg}$. (log-phase bacteria treated with formalin $3 \%, v / v$, washed twice with water, then dried at $\left.105^{\circ}\right)$. This relation did not change significantly when the bacteria were grown with erythritol. Populations below $2 \times 10^{7}$ bacteria $/ \mathrm{ml}$. were estimated by viable counts.

Examination of culture filtrates for erythritol, erythrose and erythrulose. Cultures were filtered through Oxoid (grade A.P.) membranes, de-ionized by passage through a mixed bed of Amberlite IR-120 $(\mathrm{H})$ and Permutit deacidite-G $\left(\mathrm{HCO}_{\mathbf{3}}\right)$ ionexchange resins, then submitted to paper chromatography. Chromatograms were treated with silver nitrate and sodium hydroxide reagents (Trevelyan, Proctor \& Harrison, 1950) or $p$-anisidine and periodate (Bragg \& Hough, 1958) reagents. Control experiments showed that, despite the large concentration of glucose in the medium, erythritol, erythrose or erythrulose at $\mathbf{0} \cdot 1 \mu \mathrm{mole} / \mathrm{ml}$. could be detected in culture filtrates.

Erythritol homologues. 'AnalaR' grade glycerol was supplied by British Drug Houses Ltd (Poole, Dorset). DL-threitol was prepared from 1,2-3,4-dianhydro-DLthreitol supplied by Dr G. M. Timmis. Ribitol (adonitol), D-glucitol (sorbitol), D-galactitol (dulcitol) and D-mannitol were supplied by George T. Gurr Ltd, London, and D- and L-arabitol by Mann Research Laboratories Inc. New York. For growth studies, solutions of the homologues ( $1 \mathrm{ml}$. containing $5 \mu \mathrm{mole})$ in the defined medium were mixed with the inoculated medium (4 $\mathrm{ml}$. in $25 \mathrm{ml}$. flasks) then treated as described previously for studies with erythritol.

$\left.{ }^{[14} \mathrm{C}\right]$-Labelled compounds. $\quad\left[\mathrm{U}-{ }^{14} \mathrm{C}\right]$-Erythritol $(2 \mathrm{mC} / \mathrm{mmole})$ from the Radiochemical Centre, Amersham, Buckinghamshire, was diluted (25 $\mu \mathrm{mole} / \mathrm{ml}$; $1 \mu \mathrm{C} / \mathrm{ml}$.) and stored at $-20^{\circ}$. $\left[{ }^{14} \mathrm{C}_{1}\right]$-Erythritol $(0.9 \mathrm{mC} / \mathrm{mmole})$, synthesized by Dr P. W. Kent of the University of Oxford, was treated similarly. [U-14C]-D-Glucose (8.5 mC/mmole) was also diluted $(10 \mu \mathrm{C} / \mathrm{ml}$.; negligible weight of glucose) and stored similarly.

Measurement of radioactivity. Radioactivity was measured by a 'coincidence' scintillation counting technique (Apparatus by Isotope Developments Ltd, Reading, Berkshire: liquid measuring head No. 2022, coincidence control unit No. 2032; and a decade counter) at room temperature in disposable polythene tubes $(25 \mathrm{ml}$. with 
lids; catalogue No. XT 1580; X-Lon Products Ltd, London, S.W. 1). 'Scintillation Grade' dioxane, formamide, and a dioxane-based scintillator (NE 220) were obtained from Nuclear Enterprises (G.B.) Ltd, Edinburgh. The solvents were stored under oxygen-free nitrogen but the polythene tubes were not flushed with nitrogen during assay. Replicate counts agreed within $\pm 3 \%$, but counting efficiencies (about 30-60\%) varied with the nature of the solvent mixture in which the experimental sample was examined. Thus, comparisons of experimental samples with standard amounts of radiotracer were made in identical solvent mixtures. Since some mixtures were non-aqueous, standards were dissolved in dioxane, which could be included in every solvent system. More than $10^{4}$ counts were determined for each sample and appropriate background and coincidence corrections applied.

The radioactivity of aqueous solutions or suspensions $(0.5 \mathrm{ml}$.) was measured after mixture with formamide $(0.5 \mathrm{ml}$.), dioxane $(4 \mathrm{ml}$.) and scintillator $(5 \mathrm{ml}$.) The formamide and dioxane decreased the possibility of phase separation in saline solutions. Any suspensions which were assayed in these aqueous systems were insufficiently dense to affect the counting efficiency. Samples in organic solvents (1 ml.) were mixed with dioxane $(4 \mathrm{ml}$.) and scintillator $(5 \mathrm{ml}$.) for assay. Insoluble protein residues (5-20 mg.) from the solvent extraction of bacteria (see below) were dispersed in hot $6 \mathrm{~N}-\mathrm{HCl}\left(1-5 \mathrm{ml}\right.$. at $\left.100^{\circ}\right)$. Portions $(0.5 \mathrm{ml}$.) of this suspension were mixed with water $(1 \mathrm{ml}$.) and $1.0 \mathrm{M}$-hyamine hydroxide (1 ml.; see below). Portions $(1 \mathrm{ml}$.) of this mixture with added dioxane $(4 \mathrm{ml}$.) and scintillator $(5 \mathrm{ml})$. were assayed as described above for organic solutions.

$\left[{ }^{14} \mathrm{C}\right]$-Carbon dioxide (see below) was absorbed in a methanolic solution $(0 \cdot 3 \mathrm{M})$ of hyamine hydroxide (2-methyl-4-(1, 1, 3, 3-tetramethylbutyl)-phenoxy-ethoxy-ethyldimethylbenzyl ammonium hydroxide; Passmann, Radin \& Cooper, 1956) for assay as described above for organic solvents.

Estimation of radiotracer in components of protein hydrolysates. Two-dimensional chromatograms of protein hydrolysates were placed against X-ray film (Ilford, Industrial G, $14 \times 17$ in.) in a suitable holder. After an appropriate exposure, the developed film was used to locate the individual spots; these were cut out and placed with water $(0.5 \mathrm{ml}$.) in assay tubes. The tubes were gently agitated for a few minutes and the radiotracer determined after addition of formamide $(0.5 \mathrm{ml}$.), dioxane $(4 \mathrm{ml}$.), and scintillator $(5 \mathrm{ml}$.). Duplicate chromatograms sprayed with ninhydrin reagent were used to identify the spots by comparison with standard mixtures of amino acids.

Collection of ${ }^{14} \mathrm{CO}_{2}$ produced during growth of Brucella abortus on $\left[U_{-14} C\right]$-erythritol. Narrow-necked conical flasks $(100 \mathrm{ml}$.) with rubber stoppers and provided with inlet and outlet tubes were joined to cottonwool filters by thick-walled rubber tubing. Gas flow through this tubing could be blocked with double screw clips. The length of the tubing was kept as short as possible to minimize loss of $\mathrm{CO}_{2}$ by diffusion through the rubber. Suspensions (10 ml., containing $2 \times 10^{7}$ bacteria/ml.) of the organism in medium (containing $0.5 \mu \mathrm{mole} / \mathrm{ml}$, and $0.02 \mu \mathrm{C} / \mathrm{ml}$. of [U-14 $\mathrm{C}$ ]-erythritol) were placed in the flasks. A stream of $5 \% \mathrm{CO}_{2}$ in $\operatorname{air}(\mathbf{0 . 5} \mathrm{l} . / \mathrm{min}$. for $2 \mathrm{~min}$.) was introduced and the clips on the inlet and outlet tubes were then closed. The whole apparatus was then shaken at $37^{\circ}$ in the aluminium boxes already described.

At intervals, flasks were removed and gently agitated whilst their atmospheres were flushed out with a stream of air $(0.5$ l. over 2 min.). To remove remaining 
traces of ${ }^{14} \mathrm{CO}_{2}$, carbon dioxide $(5 \mathrm{ml}$.) was flushed in with a little air and after agitation for a further minute the flasks were again flushed out with air (1.0 l. over $2 \mathrm{~min}$.). Carbon dioxide displaced from the flasks was trapped for measurement in a bubbler containing $0.3 \mathrm{M}$-methanolic hyamine hydroxide $(25 \mathrm{ml}$.). This procedure removed all ${ }^{14} \mathrm{CO}_{2}$ from the apparatus. After removal of the ${ }^{14} \mathrm{CO}_{2}$ the extinction of the bacterial suspension was measured photometrically and bacteria and supernatant fluid separated by centrifugation $(5000 \mathrm{~g}$ for $20 \mathrm{~min}$.) for radio-assay.

\section{Examination of fractions of Brucella abortus for the presence of

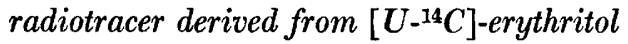

Growth of organisms. Cultures $(30 \times 100 \mathrm{ml}$. flasks each containing $10 \mathrm{ml}$. medium) of Brucella abortus (inoculum $5 \times 10^{7}$ bacteria $/ \mathrm{ml}$.) containing [U-14 $\mathrm{C}$ erythritol ( $1 \mu \mathrm{mole} / \mathrm{ml}$., $0.04 \mu \mathrm{C} / \mathrm{ml}$ ) were grown overnight in shake flasks as described previously until about $80 \%$ of the erythritol had been used. The bacteria were harvested by centrifugation, washed twice with water, then fractionated as described below and the weights and radiotracer content of the various fractions determined.

Method of fractionation. A convenient method for the solvent fractionation of Brucella abortus was developed from that of Roberts et al. (1957). A portion (equiv. about $10 \mathrm{mg}$. dry weight) of the washed bacterial suspension was dried $\left(100^{\circ}\right.$, $30 \mathrm{~min}$. to halt enzyme action; then as described below) and the remainder (equiv. about $20 \mathrm{mg}$. dry weight) was treated with $5 \%(\mathrm{w} / \mathrm{v})$ trichloroacetic acid (10 ml.) in a tared centrifuge tube. After $10 \mathrm{~min}$. insoluble material was centrifuged down, washed twice with water, dried and weighed. The residue from this extraction was treated successively with methanol $(10 \mathrm{ml}$.) and methanol + chloroform $(1+2$ by vol.; $10 \mathrm{ml}$.) then centrifuged down, dried, and weighed. The methanol + chloroform mixture (Folch et al. 1951) appeared to extract all lipid, since no appreciable amounts of bound lipid were removed by a mixture of ether + ethanol+conc. $\mathrm{HCl}(450+300+13$, by vol.; Stahl, Pennell \& Huddleson, 1939), or by extraction with ether after refluxing with methanol + water $(19+1$, by vol.; Reichert, 1944). The residue from the lipid extraction was treated with hot trichloroacetic acid $\left(5 \%, \mathrm{w} / \mathrm{v} ; 10 \mathrm{ml}\right.$. at $90^{\circ}$ for $15 \mathrm{~min}$.) then centrifuged down, washed twice with water, dried and weighed.

All fractions were dried to constant weight under reduced pressure over phosphoric oxide and paraffin chips. The lipid solvents were removed in a stream of warm nitrogen before the fraction was dried. To obtain preliminary information on the chemical nature of the fractions a large quantity ( $3 \mathrm{~g}$. dry weight) of bacteria was grown on a defined medium (Rode et al. 1950) without erythritol and extracted and examined in a similar way.

Analysis of fractions. Hydrolyses in sealed tubes were carried out with $\mathrm{N}-\mathrm{H}_{2} \mathrm{SO}_{4}$ $\left(100^{\circ}, 18 \mathrm{hr}\right.$, neutralized with $\left.\mathrm{BaCO}_{3}\right), \mathrm{N}-\mathrm{NaOH}\left(100^{\circ}, 3 \mathrm{hr}\right.$, neutralized with Amberlite IR-120 (H) ion exchange resin) and $6 \mathrm{~N}-\mathrm{HCl}\left(100^{\circ}, 18 \mathrm{hr}\right.$, dilute, filter, then concentrated to dryness to remove excess acid) as appropriate. Sugars and polyols were identified by single dimension chromatography in several solvents. Free sugars were detected with $p$-anisidine spray reagent (Hough, Jones \& Wadman, 1950) and polyols with periodate and anisidine (Bragg \& Hough, 1958) and periodate-Schiff's reagents (Baddiley, Buchanan, Handschumacher \& Prescott, 1956). Phosphates 
were detected with molybdate + perchloric acid reagent (Hanes \& Isherwood, 1949). Our colleague Mr A. G. Ness identified amino compounds by two-dimensional paper chromatography and confirmed the identity of $\alpha, \epsilon$-diaminopimelic acid (Powell \& Strange, 1956); amino compounds were detected with ninhydrin reagent (Consden \& Gordon, 1948). Similar protein hydrolysates were examined by auto-radiography, as described above.

The $\left[{ }^{14} \mathrm{C}\right]$-content of purine ribose was determined by dilution analysis. A portion (5 ml.) of the hot trichloroacetic acid extract $(10 \mathrm{ml}$.) with ribose carrier $(100 \mathrm{mg}$.) was refluxed with $\mathrm{N}-\mathrm{HCl}\left(1 \mathrm{hr}\right.$ at $\left.100^{\circ}\right)$, de-ionized, and concentrated to yield ribose on crystallization from aqueous acetone. The specific activity of this ribose remained unchanged on further recrystallization.

Further analyses were made on samples from the large scale preliminary fractionation which could not be performed on the smaller available quantities of radioactive fractions. These analyses included: nitrogen (Nesslerization after Kjeldahl digestion); total phosphorus (after perchloric acid digestion; King, 1951); protein (Lowry et al. 1951; against human serum albumin as a standard after dispersion in $\mathrm{N}-\mathrm{NaOH}$ at $100^{\circ}$ for 5 min.); polysaccharide as glucose (Dische, 1955); DNA (diphenylamine reaction against purified calf thymus DNA as standard) and RNA (orcinol reaction against purified ribose as a standard) by the methods of Morse \& Carter (1949); nucleotides spectrophotometrically (assuming $\epsilon_{260} \mathrm{~m}_{\mu} \mathbf{M}$ for nucleotides $=10^{4}$ ) by our colleague Mr H. E. Wade.

Preparation of cell walls from Brucella abortus which had metabolized $\left[{ }^{14} C_{1}\right]-$, and $\left[U-{ }^{14} C\right]$-erythritol. The organism was grown in the presence of the two forms of $\left[{ }^{14} \mathrm{C}\right]$-erythritol as previously described, then harvested by centrifugation and diluted with carrier bacteria to form a sufficient quantity for disintegration (100 mg.). Cell walls were then prepared by disintegration (apparatus by $\mathbf{H}$. Mickle, Hampton, Middlesex), treatment with heat $\left(60^{\circ}\right.$ for $\left.1 \mathrm{hr}\right)$, DNAase and RNAase, and purification by centrifugation (Dr D. C. Ellwood; private communication).

Effect of erythritol and 2-deoxy-2-fluoro-DL-erythritol on glucose incorporation by Brucella abortus. To obtain a measurable uptake of radioactivity by the comparatively small amount of bacteria (this is limited by the available erythritol), the normal glucose content ( $39 \mu \mathrm{mole} / \mathrm{ml}$.) of the defined medium had to be decreased and $\left[\mathrm{U}-{ }^{14} \mathrm{C}\right]-\mathrm{D}$-glucose of high specific activity had to be used. The modified medium contained $\left[\mathrm{U}-{ }^{14} \mathrm{C}\right]-\mathrm{D}-$ glucose $(5 \mu \mathrm{mole} / \mathrm{ml},, \quad 0 \cdot 2 \mu \mathrm{C} / \mathrm{ml}$.) with additional $\mathrm{NaCl}$ (1 mg./ml.). This medium ( $1 \mathrm{ml}$.) alone, or containing either erythritol (10 $\mu$ mole/ $\mathrm{ml}$.) or 2-deoxy-2-fluoro-DL-erythritol (10 $\mu \mathrm{mole} / \mathrm{ml}$.), was dispensed into flasks $\left(100 \mathrm{ml}\right.$.). Additional medium $\left(9 \mathrm{ml}\right.$.) inoculated with the organism $\left(1.0 \times 10^{8}\right.$ bacteria/ml.) was then added and growth under the standard conditions in shake culture determined as described previously. Heat-killed bacteria $\left(60^{\circ}, 1 \mathrm{hr}, 3 \cdot 5 \mathrm{mg}\right.$. dry wt) were added as carrier to portions $(9 \mathrm{ml}$.) of the suspensions of radioactive bacteria. After centrifugation $(5000 \mathrm{~g} ; 20 \mathrm{~min}$.) the bacteria were washed (original medium containing [ $\left.{ }^{12} \mathrm{C}\right]-\mathrm{D}$-glucose instead of the radiotracer; $10 \mathrm{ml}$.) and suspended in formol saline $(3 \%, \mathrm{v} / \mathrm{v})$ for radio-assay. The heat-killed bacteria did not absorb radiotracer when added alone to the labelled medium. 


\section{Short-term uptake of $\left[U{ }^{-14} C\right]$-erythritol and $\left[U-{ }^{14} C\right]$-D-glucose by dense suspensions of Brucella abortus}

Apparatus. 'Medical flat' bottles (8 oz.) were provided with metal screw tops in which were punched several small holes so that, although the punched cap with its intact rubber washer formed a secure seal, samples of the contents could be removed with a hypodermic syringe. A slight vacuum was maintained in the bottles and a tight rubber cap was fitted over the top to prevent contamination during sampling. Bottles were filled and handled at $37^{\circ}$ and during the uptake studies were rotated end over end (60 rev./min.).

Uptake of $\left[U_{-14}{ }^{14}\right]$-erythritol. The virulent organism (Brucella abortus strain 544) was grown on standard medium supplemented with erythritol $1 \mu \mathrm{mole} / \mathrm{ml}$. and harvested by centrifugation before the erythritol was depleted. After re-suspension in fresh medium, the suspension was rotated in the 'medical flat' (5\% $\mathrm{CO}_{2}$ in air) for $10 \mathrm{~min}$. before injection of [U-14C]-erythritol through the cap. A sample $(4 \mathrm{ml}$.) of the bacterial suspension (initially $60 \mathrm{ml}$. containing equiv. $200 \mu \mathrm{g}$. dry weight bacteria $/ \mathrm{ml}$. and $\left[\mathrm{U}-{ }^{14} \mathrm{C}\right]$-erythritol $0.5 \mu \mathrm{mole} / \mathrm{ml}$., $0.020 \mu \mathrm{C} / \mathrm{ml}$.) was withdrawn immediately and further samples were taken at convenient intervals over $40 \mathrm{~min}$. The samples were filtered quickly through a double 'Oxoid' membrane (grade A.P.) to separate the culture medium for determination of radiotracer loss.

Uptake of $\left[U-{ }^{14} C\right]-D$-glucose in the presence and absence of erythritol. Cells were grown as described above for the virulent strain of Brucella abortus and the uptake of $\left[\mathrm{U}-{ }^{14} \mathrm{C}\right]-\mathrm{D}$-glucose was studied in a similar manner. The quantity of bacteria required for this work (i.e. those harvested during log phase before erythritol depletion) was limited. Hence, to obtain a measurable loss of radiotracer from the medium by the relatively small quantity of bacteria, the concentration of glucose in the normal medium ( $39 \mathrm{~mole} / \mathrm{ml}$.) had to be drastically decreased. One 'medical flat' contained bacteria (equiv. $200 \mu \mathrm{g}$. dry weight $/ \mathrm{ml}$.) and the defined medium with the glucose content decreased to $0.5 \mu \mathrm{mole} / \mathrm{ml}$. $(0.02 \mu \mathrm{C} / \mathrm{ml}$.). A second 'medical flat' contained the same system with added erythritol (0.5 $\mu$ mole $/ \mathrm{ml}$.).

Examination of a hot water extract of Brucella abortus for erythritol. The organisms were grown in the presence of [U-14 $\mathrm{C}]$-erythritol as described previously. The washed bacteria (equiv. about $20 \mathrm{mg}$. dry weight) were treated with water $(10 \mathrm{ml}$.) at $100^{\circ}$; the extract was de-ionized, treated with $\mathrm{Na}_{2} \mathrm{CO}_{3}\left(2 \%, \mathrm{w} / \mathrm{v} ; 100^{\circ} ; 30 \mathrm{~min}.\right)$ and then de-ionized again (Adcock, 1957). The concentrated extract was examined chromatographically for radioactive erythritol.

Attempts to obtain broken-cell preparations which would metabolize erythritol. Organisms were grown on the standard medium supplemented with erythritol ( $1 \mu \mathrm{mole} / \mathrm{ml}$.) and harvested by centrifugation before depletion of the erythritol. The bacteria were disrupted by disintegration of a suspension with glass beads (apparatus by $\mathbf{H}$. Mickle, Hampton, Middlesex), by alternate freezing and thawing (Gerhardt et al. 1953) and by disintegration of a frozen suspension in a suitable press (Hughes, 1951).

The various preparations (final concentrations equal to whole bacteria, $1 \mathrm{mg} . / \mathrm{ml}$. were incubated $\left(37^{\circ}\right)$ with, and without, glucose $(7 \mathrm{mg} . / \mathrm{ml}$.$) in a buffer \left(\mathbf{K}_{2} \mathbf{H P O}_{4}\right.$, $0 \cdot 10 \% ; \mathrm{NaH}_{2} \mathrm{PO}_{4} .2 \mathrm{H}_{2} \mathrm{O}, 0 \cdot 33 \% ; \mathrm{NaCl}, 0 \cdot 10 \% ; \mathrm{MgSO}_{4} .7 \mathrm{H}_{2} \mathrm{O}, 0.07 \% ; \mathrm{pH} 7 \cdot 0$ ) containing NAD, NADP, ATP (0.02 $\mu \mathrm{mole} / \mathrm{ml}$. each) and [U-14 C]-erythritol (0.5 $\mu$ mole/ 
ml., $0 \cdot 02 \mu \mathrm{C} / \mathrm{ml}$.) Samples $(1 \mathrm{ml}$.) withdrawn at intervals up to $30 \mathrm{~min}$. were heated $\left(100^{\circ}, 2 \mathrm{~min}\right.$.) to halt enzyme activity then diluted to $5 \mathrm{ml}$. and filtered through Oxoid membranes (grade AP). The filtrate was treated $\left(100^{\circ}, 2 \mathrm{hr}\right.$ ) with Biodeminrolite (Permutit Co. Ltd, London, W. 4) mixed-bed ion-exchange resin (2 g.) to remove ionic compounds and sugars from polyols (Anderson, Andrews \& Hough, 1961). After dilution to $10 \mathrm{ml}$. the radiotracer content of the supernatant fluids were determined as a measure of their erythritol content, on the assumption that products of erythritol metabolism would be associated with the cell debris or be removed by the mixed-bed resin.

\section{RESULTS}

The metabolism of erythritol by Brucella abortus during growth in the presence of an optimum (high) concentration of glucose

In previous work with small inocula (see references in Introduction) minute quantities of erythritol (less than $0.01 \mu \mathrm{mole} / \mathrm{ml}$.) stimulated the growth of Brucella abortus in bovine phagocytes and in laboratory media. Similarly, in the present work with a defined medium, small quantities of erythritol $(0.005 \mu \mathrm{mole} / \mathrm{ml}$. $)$ had a significant effect on the growth of $B$. abortus provided that the inoculum was small (about $1 \times 10^{4}$ bacteria $/ \mathrm{ml}$.). However, larger quantities of erythritol were needed if the inoculum was to be sufficiently large (about $2.5 \times 10^{7}$ bacteria $/ \mathrm{ml}$.) to allow increases in growth to be followed turbidimetrically.

Fig. 1 shows the effect of various concentrations of erythritol on the growth of Brucella abortus strain 544. Stimulation of growth continued for a period which was determined by the original concentration of erythritol. After this period, the growth rate approached that of the control. These results suggest that, despite the presence of an optimum high concentration of glucose, erythritol was a main carbon or energy source and had been exhausted at the points of inflexion of the curves. Examination of culture filtrates obtained in similar growth experiments with various concentrations of erythritol up to $5 \mu \mathrm{mole} / \mathrm{ml}$. confirmed that at the points of inflexion of the growth curves all detectable erythritol had disappeared. At these inflexion points, the ratios of erythritol used to dry weight of bacteria formed were from $1: 1 \cdot 4$ to $1: 2 \cdot 0$. A similar large usage of erythritol by $B$. abortus was confirmed in experiments with small inocula (about $1 \times 10^{4}$ bacteria $/ \mathrm{ml}$.).

Although a large quantity of erythritol was needed to produce the growth stimulation of Brucella abortus in this system containing glucose, too high an initial concentration of erythritol (about $10-50 \mu \mathrm{mole} / \mathrm{ml}$. for an inoculum of $5 \times 10^{7}$ bacteria/ml.) was inhibitory. For this reason, the initial concentration was related to the size of the original inoculum to produce the maximum stimulation of growth. Erythritol concentrations up to $5 \mu \mathrm{mole} / \mathrm{ml}$. have been used in this work.

\section{The specificity of the effect of erythritol on Brucella abortus in a medium containing glucose}

A wide range of erythritol homologues had little effect on the growth of the organism in this medium containing glucose (Table 2). This specificity of growth enhancement by erythritol was supported by the inhibition of the growth of Brucella abortus, in vitro and in vivo, by analogues of erythritol (Smith et al. 1964). The effect of one of these analogues (2-deoxy-2-fluoro-DL-erythritol) on glucose utilization by 
$B$. abortus will be discussed later; its inhibitory effect on growth and the annulment of this inhibition by addition of erythritol is shown in Table 2.

The fate of erythritol when metabolized by Brucella abortus in the presence of glucose

The results of radiotracer studies on the growth of Brucella abortus with [U-14 $\mathrm{C}$ erythritol $(0.5 \mu \mathrm{mole} / \mathrm{ml}$.), shown in Fig. 2, indicated that all erythritol had been depleted at 19-20 hr; this was confirmed by analysis of the culture filtrates. At this time, the ratio of erythritol used to weight of organisms formed was $1: 1 \cdot 4$ (see above). At $21 \mathrm{hr}$, the distribution of original activity was : bacteria $23 \%$, medium $37 \%$,

Table 2. The action of erythritol homologues and analogues on the growth of Brucella abortus in a medium containing glucose

$\begin{array}{cc} & \begin{array}{c}\text { Population at } \\ 16 \mathrm{hr} \text { as \% of } \\ \text { population of }\end{array} \\ \text { Substrates }(1 \mu \mathrm{mole} / \mathrm{ml} \text {.) } & \text { a control }\end{array}$

Glycerol

DL-Threitol

Ribitol

Xylitol

D-Arabitol

L-Arabitol

D-Glucitol

D-Galactitol

D-Mannitol

D-Erythrose

Erythritol

2-Deoxy-2-fluoro-DL-erythritol

2-Deoxy-2-fluoro-DL-erythritol

+erythritol

$$
\}
$$

$100( \pm 5)^{*}$

$125^{*}$

225

64

195

* At $40 \mathrm{hr}$ similar ratios were obtained.

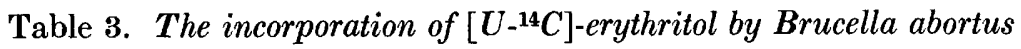
during growth in the presence of glucose

$\begin{array}{cc}\begin{array}{c}\text { Period of growth } \\ \text { (hr) }\end{array} & \begin{array}{c}\text { Carbon ex erythritol } \\ \text { Total cell carbon }\end{array} \\ 12 & 20 \\ 14 & 26 \\ 16 & 24 \\ 19 & 22 \\ 21 & 22\end{array}$

Erythritol depleted after $21 \mathrm{hr}$

39

5

carbon dioxide $40 \%$; thus indicating that erythritol was used as a general carbon and energy source.

Material in the medium containing radiotracer has not been identified but paper chromatography has excluded the presence of significant amounts of erythrose or erythrulose which might have been formed by the partial oxidation of erythritol as occurs with Acetobacter suboxydans (Whistler \& Underkofler, 1938). Only small 
amounts of radiotracer were present in glucose and glycerol regions of autoradiograms, although large amounts of glycerol were excreted into the medium.

The results in Table 3 show that up to the time when the polyol was depleted only about one-quarter of the carbon content of the organisms (assumed to be $55 \%$ of the dry weight) was derived from erythritol despite the fact that the bacteria had used approximately $1 \frac{1}{2}$ times their own weight of erythritol during growth.

\section{The incorporation of $\left[U^{-14} \mathrm{C}\right]$-erythritol into cell fractions of Brucella abortus}

Table 4 summarizes the distribution of activity and the nature and yield of fractions obtained from Brucella abortus 544 grown in the presence of $\left[\mathrm{U}-{ }^{14} \mathrm{C}\right]$ erythritol until about $\mathbf{8 0} \%$ of the erythritol had been depleted. Evidence on the chemical nature of fractions shown in Table 4 was supplemented by the following

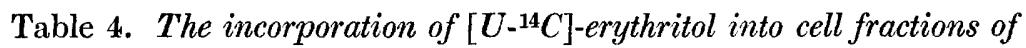
Brucella abortus

\section{Fraction}

Material soluble in cold trichloroacetic acid

Material soluble in methanol and in methanol + chloroform

Material soluble in hot trichloroacetic acid

Insoluble cell residue

$\begin{array}{lcc}\text { Brucella abortus } & \begin{array}{c}\text { Weight } \\ \text { as } \\ \% \text { of dry } \\ \text { weight of } \\ \text { organism }\end{array} & \begin{array}{c}\text { Radio- } \\ \text { activity as } \\ \text { activity in } \\ \text { organism }\end{array} \\ \begin{array}{l}\text { Diffusible material (about 70\%) with a non- } \\ \text { diffusible residue containing glucose, } \\ \text { glycerol, ethanolamine and amino acids }\end{array} & 17 \cdot 4 & 11 \cdot 6 \\ \begin{array}{l}\text { Lipids containing fatty acids, glycerol, ethanol- } \\ \text { amine, phosphate and traces of amino acids }\end{array} & 15 \cdot 7 & \mathbf{1 4 \cdot 3} \\ \begin{array}{l}\text { Nucleic acids } \\ \text { Protein containing large amounts of valine, } \\ \text { alanine, the leucines, glutamic and aspartic } \\ \text { acids with lesser amounts of serine, glycine, } \\ \text { threonine, arginine, lysine and tyrosine and } \\ \text { with traces of histidine, proline, phenylalanine, } \\ \text { methionine and } \alpha, \epsilon \text {-diaminopimelic acid }\end{array} & & \\ \end{array}$

analyses (expressed as \% of dry weight of original bacteria) of the fractions obtained from a large quantity of $\boldsymbol{B}$. abortus in a preliminary experiment: material soluble in trichloroacetic acid, 14\% (containing diffusible material $70 \%$ including $12 \%$ nucleotides, and $30 \%$ of non-diffusible material including $30 \%$ glucose and $10 \%$ protein); the lipid fraction, $\mathbf{1 1 . 4} \%$ (containing $53 \%$ acetone-insoluble material, $\mathrm{P}, \mathbf{2 . 6} \% ; \mathrm{N}, \mathbf{4} \cdot \mathbf{2} \%$; and $47 \%$ of an acetone-soluble material, $\mathrm{P}, 0.9 \% ; \mathrm{N}$, nil); the nucleic acid fraction, $10.5 \%$ (containing $66 \%$ RNA and $34 \%$ DNA); and the insoluble residue, $66 \%$ (containing $98 \%$ protein).

The even distribution of radiotracer over all fractions is apparent. Further evidence that radiotracer was evenly distributed within the solvent fractions was provided by the study of two selected cases, namely, the purine-bound ribose of the nucleic acids and the amino acids obtained on hydrolysis of the protein residue. The purine-bound ribose contained $17 \%$ of the total radioactivity and made up $18 \%$ of 
the total carbon in this fraction (assuming the fraction was $67 \%$ RNA and $26 \%$ of the RNA carbon was in purine-bound ribose). The distribution of radioactivity in the amino acids of the protein fraction (see Table 5) roughly correlated with the relative amounts of the individual components (estimated by visual comparison of spots on paper chromatograms). No single amino acid appeared to contain an undue proportion of the radio-activity.

Table 5. Radiotracer content of the amino acids in the protein of Brucella abortus grown in the presence of glucose and $\left[U^{-14} \mathrm{C}\right]$-erythritol

\begin{tabular}{|c|c|c|c|}
\hline Amino acid & $\begin{array}{c}{\left[{ }^{14} \mathrm{C}\right] \text {-Content }} \\
\text { of individual } \\
\text { amino acids as } \\
\% \text { of }\left[{ }^{14} \mathrm{C}\right] \text { in } \\
\text { hydrolysate }\end{array}$ & Amino acid & $\begin{array}{l}{\left[{ }^{14} \mathrm{C}\right] \text {-Content }} \\
\text { of individual } \\
\text { amino acids as } \\
\% \text { of }\left[{ }^{14} \mathrm{C}\right] \text { in } \\
\text { hydrolysate }\end{array}$ \\
\hline Aspartic acid & 15 & Arginine & 5 \\
\hline Leucines & 15 & Threonine & 5 \\
\hline Alanine & 14 & Phenylalanine & 2 \\
\hline Glutamic acid & 11 & & (approx.) \\
\hline Valine & 8 & Methionine & $1 \cdot 4$ \\
\hline Lysine & 8 & Histidine & $0 \cdot 3$ \\
\hline Tyrosine & 8 & $\alpha \epsilon$-diaminopimelic acid & $0 \cdot 3$ \\
\hline Serine + glycine & 6 & Unidentified spots & $4 \cdot 35$ \\
\hline
\end{tabular}

The incorporation of $\left[{ }^{14} \mathrm{C}\right]$-erythritol into the cell wall of Brucella abortus

A cell-wall preparation of Brucella abortus 544 formed $29.7 \%$ of the dry weight of organisms which had been grown in the standard medium in the presence of erythritol. Similar preparations from bacteria grown in the presence of $\left[{ }^{14} C_{1}\right]$ - and [U $\left.{ }^{14} \mathrm{C}\right]$-erythritol contained 29 and $31 \%$, respectively, of the total activity of the bacteria, thus confirming the random distribution of carbon from erythritol among cell components.

The effect of erythritol and 2-deoxy-2-fluoro-DL-erythritol on the incorporation of $\left[U-{ }^{14} C\right]-D$-glucose by Brucella abortus

The results summarized in Table 6 show that erythritol and the fluoro analogue depressed the percentage incorporation of glucose by the organism but that once the erythritol had been depleted the incorporation approached that of the control.

Table 6. The action of erythritol and 2-deoxy-2-fluoro-DL-erythritol on the incorporation of $\left[U-{ }^{14} C\right]-D$-glucose by Brucella abortus

\begin{tabular}{|c|c|c|c|}
\hline $\begin{array}{l}\text { Period of } \\
\text { growth (hr) }\end{array}$ & Control & $\begin{array}{l}1 \mu \mathrm{mole} / \mathrm{ml} \text {. } \\
\text { 2-deoxy-2- } \\
\text { fluoro-DL- } \\
\text { erythritol }\end{array}$ & $\begin{array}{c}1 \mu \mathrm{mole} / \mathrm{ml} . \\
\text { erythritol }\end{array}$ \\
\hline 16 & 22 & 16 & 16 \\
\hline 20 & 26 & 16 & 19 \\
\hline 23 & 29 & 19 & 19 \\
\hline 40 & 49 & 35 & $46^{*}$ \\
\hline
\end{tabular}

* The erythritol had been used up at about $30 \mathrm{hr}$. 
The short-term uptake of $\left[U-{ }^{14} C\right]$-erythritol and $\left[U-{ }^{14} C\right]-D-g l u c o s e ~ b y$ dense suspensions of Brucella abortus

One reason why erythritol was used preferentially by Brucella abortus in the medium containing glucose might have been that erythritol entered the bacteria more rapidly than did glucose. Hence short-term uptake experiments were done, but, for reasons described in Methods, uptake of glucose could not be studied at the high concentration normally present in the medium used in most of this work (39 $\mu \mathrm{mole} / \mathrm{ml}$.). Nevertheless, the curves in Fig. 3 show that, at a glucose concentration $(0.5 \mu \mathrm{mole} / \mathrm{ml}$.) equal to that of the erythritol, the rate of loss of glucose from the medium was only about half that of erythritol.

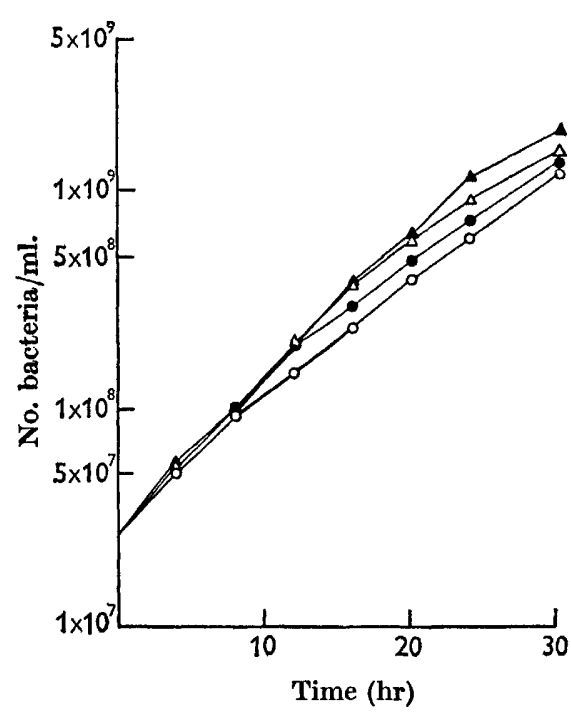

Fig. 1

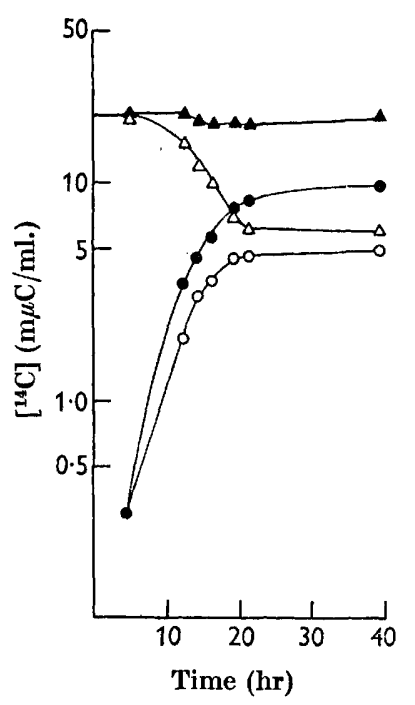

Fig. 2

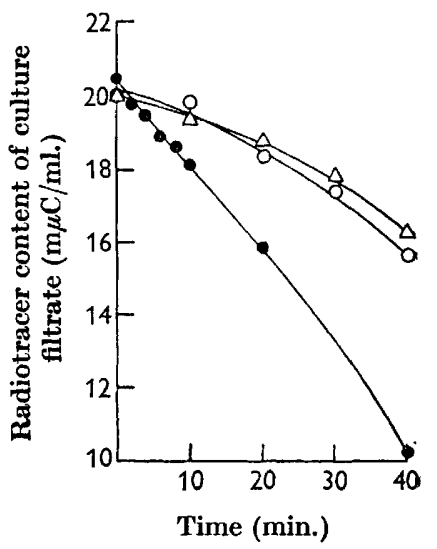

Fig. 3

Fig. 1. Growth of Brucella abortus in the presence of glucose $(39 \mu \mathrm{mole} / \mathrm{ml}$.) and initial erythritol concentrations of: $\left.0(-)_{-}-\right), 0 \cdot 1 \quad(-\odot-\odot-), 0.33(-\triangle-\triangle-)$, and $1 \cdot 0(-\Delta-\Delta-)$ $\mu \mathrm{mole} / \mathrm{ml}$.

Fig. 2. The distribution of radiotracer in bacteria $(-\bigcirc-\bigcirc-)$, medium $(-\triangle-\triangle-)$, and carbon dioxide (-O-O-) during growth of Brucella abortus in the presence of glucose and $\left[\mathrm{U}-{ }^{14} \mathrm{C}\right]$-erythritol; total recovery of radiotracer shown thus: $-\boldsymbol{\Delta}-\boldsymbol{\Delta}$-.

Fig. 3. The uptake of $\left[\mathrm{U}^{14} \mathrm{C}\right]$-erythritol and $\left[\mathrm{U}-{ }^{14} \mathrm{C}\right]-\mathrm{D}$-glucose by dense $(200 \mu \mathrm{g} . / \mathrm{ml}$. suspensions of Brucella abortus. -O-O- uptake of [U-14 C]-erythritol $(0 \cdot 5 \mu \mathrm{mole} / \mathrm{ml}$; $0.020 \mu \mathrm{C} / \mathrm{ml}$.) in the presence of a large amount of glucose $(39 \mu \mathrm{mole} / \mathrm{ml}$.); - $-\bigcirc-$ uptake of [U-14 $\mathrm{C}]-\mathrm{D}$-glucose $(0.020 \mu \mathrm{C} / \mathrm{ml}$.) in the same medium containing only a small amount $\left(0.5 \mu \mathrm{mole} / \mathrm{ml}\right.$.) of glucose; and $-\triangle-\Delta-$ uptake of $\left[\mathrm{U}_{-14}{ }^{4} \mathrm{C}\right]-\mathrm{D}$-glucose $(0.5 \mu \mathrm{mole} / \mathrm{ml}$; $0.020 \mu \mathrm{C} / \mathrm{ml}$.) in the presence of erythritol $(0.5 \mu \mathrm{mole} / \mathrm{ml}$. $)$.

The curves in Fig. 3 show that there was no initial rapid uptake of erythritol (or glucose), indicating no significant accumulation of free polyol and that the rates of uptake and metabolism were balanced. This was supported by the absence (less than $\mathbf{0 . 0 0 0 5} \%$ of the dry weight) of free erythritol from hot water extracts of bacteria which had been grown with $\left[\mathrm{U}-{ }^{14} \mathrm{C}\right]$-erythritol and from the cold trichloroacetic acid extract of the solvent fractionation procedure. Erythritol had no appreciable effect on the total uptake of glucose (see Fig. 3) but since the growth rate was increased 
by erythritol the \% incorporation of glucose into the organism was decreased (see above).

Attempts to demonstrate metabolism of erythritol by broken-cell suspensions. The three broken-cell preparations described in Methods did not appear to metabolize $\left[\mathrm{U}-{ }^{14} \mathrm{C}\right]$-erythritol under the experimental conditions.

\section{DISCUSSION}

The stimulatory effect described previously of very small quantities of erythritol on the growth of Brucella abortus was observed because small populations were used in those preliminary investigations (references in Introduction). Work with larger populations has now shown that, in fact, $B$. abortus utilizes about $1 \frac{1}{2}$ times its own weight of erythritol. This utilization occurred during growth in a medium which contained a large excess of amino acids (1180 $\mu \mathrm{g} . / \mathrm{ml}$.) and an optimum concentration of glucose $(7000 \mu \mathrm{g} . / \mathrm{ml}$.). In most experiments initial glucose : erythritol ratios were approximately $115: 1$; in experiments with small inocula these ratios were much higher $(10,000: 1)$ and rose even further as the erythritol was preferentially consumed. Obviously erythritol is a main carbon and energy source for B. abortus, which appears to have a mechanism for the preferential uptake or metabolism of erythritol in the presence of an excess of glucose and other potential metabolites. Sorbitol and fructose are found along with glucose in bovine foetal fluids and it was interesting that the stimulatory effect of erythritol still took place when glucose was replaced by either of these carbohydrates.

The effect of erythritol appears to be highly specific since several of $\mathrm{C}_{3}$ to $\mathrm{C}_{6}$ homologues had no stimulatory effect and Smith et al. (1964) showed that erythritol annulled the inhibition of the growth of Brucella by analogues of erythritol.

Radiotracer studies confirmed that erythritol was used as a general carbon and energy source. A large proportion of the radiotracer was converted to carbon dioxide and the tracer in the cell substance was fairly evenly distributed over all cell components; erythritol is thus probably broken down to small units during metabolism.

Efforts to show that the preferential usage of erythritol was due to a more rapid entry than glucose into the cell were inconclusive. As yet no cell-free system has been obtained which will metabolize erythritol and the influence of permeability cannot therefore be assessed. Furthermore, comparison of the short-term uptake of erythritol and glucose could not be conducted with the normal very high concentration of glucose; experiments with low glucose concentrations indicated that the rate of uptake of the two carbohydrates was not very different. The absence of detectable amounts of erythritol within the bacteria suggests that the rate of metabolism was not slower than that of permeation, which might well be the ratedetermining factor.

A connexion between erythritol metabolism and glucose metabolism was indicated by the inhibitory effect of erythritol and 2-deoxy-2-fluoro-DL-erythritol on glucose incorporation. This might have been an effect on carbohydrate transport, but another possible mechanism is the inhibition of phosphoglucose isomerase or transketolase by erythrose-4-phosphate, a possible product of erythritol metabolism (Grazi, Deflora \& Pontremoli, 1960; Dische \& Igals, 1961). 
No evidence was obtained about the mechanism of erythritol metabolism in Brucella abortus. Oxidation to erythrose-4-phosphate would be a possible entry point into the pentose phosphate cycle (Horecker, Smyrniotis, Hiatt \& Marks, 1955). On the other hand, the degree of incorporation of radiotracer into ribose and the wide distribution of activity in $\boldsymbol{B}$. abortus suggests that the immediate products of erythritol metabolism enter the tricarboxylic acid cycle by a more direct route. $\mathbf{A}$ more selective pattern of incorporation of the radiotracer would probably have occurred if much carbon dioxide from erythritol metabolism had been re-utilized (Newton, Marr \& Wilson, 1954; Tepper \& Wilson, 1958). Metabolism of erythritol might occur by a reversal of mechanisms known to produce erythritol or its immediate oxidation products, e.g. the aldol condensation of formaldehyde and dihydroxyacetone to an erythrulose-1-phosphate (Charalampous, 1954; Peanasky \& Hardy, 1958), the metabolism of hydroxypyruvic acid to L-erythrulose (Dickens \& Williamson, 1956), the metabolism of dihydroxymaleic acid to D-erythrose and D-erythrulose (Akabori, Uehara \& Muramatsu, 1952), and the dismutation of D-erythrose into D-erythronic acid and erythritol (Uehara, Sugeno \& Mizoguchi, 1963).

We are most grateful to the late Professor D. D. Woods, Professor E. F. Gale, ProfessorS. R. Elsden and Dr J. L. Peel for their helpful discussions and suggestions during this work. We are indebted to Mr G. N. Wade for excellent experimental assistance.

\section{REFERENCES}

Apcock, L. H. (1957). The determination of sorbitol. Analyst. 82, 42\%.

Akabori, S., Uehara, K. \& Muramatsu, I. (1952). In Japanese. On the biochemical formation of monosaccharides. Proc. imp. Acad. Japan, 28, 39.

Anderson, J. D., Andrews, P. \& Hough, L. (1961). The biosynthesis and metabolism of polyols: sorbitol (D-glucitol) of plum leaves. Biochem. J. 81, 149.

Anderson, J. D. \& Smith, H. (1963). The metabolism of erythritol by a virulent strain of Brucella abortus. J. gen. Microbiol. 31, xxiii.

Baddiley, J., Buchanan, J. G., Handschumacher, R. E. \& Prescott, J. F. (1956). Chemical studies on the biosynthesis of purine nucleotides. Part 1 . The preparation of N-glycylglycosylamines. J. chem. Soc. p. 2818.

BragG, P. D. \& Hovgh, L. (1958). The oxidation of proline, hydroxyproline, and $\mathrm{N}$ methylglycine with periodate. J. chem. Soc. p. 4050.

Charalampous, F. C. (1954). Mechanism of formation of erythrulose-1-phosphate by phosphoketotetrose aldolase of rat liver. J. biol. Chem. 211, 249.

Consden, R. \& Gordon, A. H. (1948). Effect of salt on partition chromatograms. Nature, Lond. 162, 180.

Dickens, F. \& Williamson, D. H. (1956). Formation of erythrulose from hydroxypyruvate in the presence of yeast carboxylase. Nature, Lond. 178, 1349.

DISCHE, Z. (1955). New color reactions for determination of sugars in polysaccharides, Meth. biochem. Analysis, 2, p. 327.

Dische, Z. \& Igals, D. (1961). Mechanisms in the interconversion of ribose-5-phosphate and hexose-6-phosphate in human haemolysates. II. Erythrose-4-phosphate as an intermediate and rate regulator in the interconversion of ribose-5-phosphate and hexose-6-phosphate. Arch. Biochem. Biophys. 93, 201.

Folch, J., Ascoli, I., Lees, M., Meath, J. A. \& Lebaron, F. N. (1951). Preparation of lipide extracts from brain tissue. J. biol. Chem. 191, 833.

Gerhardt, P., Macgregor, D. R., Marr, A. G., Olsen, C. B. \& Wirson, J. B. (1953). The metabolism of brucellae: the role of cellular permeability. J. Bact. $65,581$. 
Grazi, E., Deflora, A. \& Pontremoli, S. (1960). The inhibition of phospho-glucose isomerase by D-erythrose-4-phosphate. Biochem. biophys. Res. Comm. $2,121$.

Hanes, C. S. \& Isherwood, F. A. (1949). Separation of the phosphoric esters on the filter paper chromatogram. Nature, Lond. 164, 1107.

Horecker, B. L., Smyrniotis, P. Z., Hiatt, H. H. \& Marks, P. A. (1955). Tetrose phosphate and the formation of sedoheptulose diphosphate. J. biol. Chem. 212, 827.

Hovgh, L., Jones, J. K. N. \& Wadman, W. H. (1950). Quantitative analysis of mixtures of sugars by the method of partition chromatography. Part V. Improved methods for the separation and detection of sugars and their methylated derivatives on the paper chromatogram. J. chem. Soc. p. 1702.

Hughes, D. E. (1951). A press for disrupting bacteria and other micro-organisms. Brit. J. exp. Path. 32, 97.

Keppie, J., Williams, A. E., WitT, K. \& Smith, H. (1965). The role of erythritol in the tissue localization of the brucellae. Brit. J. exp. Path. 46 (In the Press.)

KING, E. J. (1951). Microanalysis in Medical Biochemistry, 2nd ed., pp. 42, 63. London: J. and A. Churchill.

Lowry, O. H., Rosebrough, N. J., Farr, A. L. \& Randall, R. J. (1951). Protein measurement with the Folin phenol reagent. J. biol. Chem. 193, 265.

McCullough, N. B. \& Beal, G. A. (1951). Growth and manometric studies on carbohydrate utilization of Brucella. J. infect. Dis. 89, 266.

Morse, M. L. \& Carter, C. E. (1949). The synthesis of nucleic acid in cultures of Escherichia coli, strains $\mathrm{B}$ and $\mathrm{B} / \mathrm{R}$. J. Bact. 58, 317.

Newton, J. W., Marr, A. G. \& Wilson, J. B. (1954). 'The fixation of ${ }^{14} \mathrm{CO}_{2}$ into nucleic acid constituents by Brucella abortus. J. Bact. 67, 233.

Passmann, J. M., Radin, N. S. \& Cooper, J. A. D. (1956). Liquid scintillation technique for measuring carbon-14-dioxide activity. Analyt. Chem. 28, 484.

Peanasky, R. V. \& Hardy, H. A. (1958). Bovine liver aldolase. 1. Isolation, crystallization, and some general properties. J. biol. Chem. 233, 365.

Pearce, J. H., Williams, A. E., Harris-Smith, P. W., Fitzgeorge, R. B. \& SmiтH, H. (1962). The chemical basis of the virulence of Brucella abortus. II. Erythritol, a constituent of bovine foetal fluids which stimulates the growth of $\mathrm{Br}$. abortus in bovine phagocytes. Brit. J. exp. Path. 43, 31.

Powell, J. F. \& Strange, R. E. (1956). Biochemical changes occurring during sporulation in Bacillus species. Biochem. J. 63, 661 .

Reichert, R. (1944). Lipoids in yeast. (In German.) Helv. chim. acta, 27, 961.

Roberts, R. B., Cowie, D. B., Abelson, P. H., Bolton, E. I. \& Britten, R. J. (1957). Studies of Biosynthesis in Escherichia coli. Carnegie Inst. of Washington, publication 607. Washington D.C.: Kirby Lithographic Co.

Rode, I. J., Oglessy, G. \& Schunardt, V. T. (1950). The cultivation of brucellae on chemically defined media. J. Bact. 60, 661 .

Smith, H., Anderson, J. D., Keppie, J., Kent, P. W. \& Timmis, G. (1964). The inhibition of the growth of brucellae in vitro and in vivo by analogues of erythritol. J. gen. Microbiol. 38, 1 .

Smith, H., Williams, A. E., Pearce, J. H., Keppie, J., Harris-Smith, P. W., FitzGEORge, R. B. \& WrTT, K. (1962). Foetal erythritol: a cause of the localization of Brucella abortus in bovine contagious abortion. Nature, Lond. 193, 47.

Stahl, W. H., Penneli, R. B. \& Huddleson, I. F. (1939). A study of the protein nucleates of the species of the genus Brucella. Tech. Bull. Mich. agric. Exp. Sta. $168,1$.

Tepper, B. S. \& Wilson, J. B. (1958). The fixation and distribution of ${ }^{14} \mathrm{CO}_{2}$ in Brucella abortus. J. Bact. 76, 24.

Trevelyan, W. E., Proctor, D. P. \& Harrison, J. S. (1950). Detection of sugars on paper chromatograms. Nature, Lond. 166, 444.

Uehara, K., Sugeno, K. \& Mizoguchi T. (1963). Studies on D-tetrose metabolism II. An enzyme from beef liver catalysing dismutation of D-tetrose. J. Vitaminol. 9, 206.

Whistler, R. L. \& Underkofler, L. A. (1938). The production of L-erythrulose by the action of Acetobacter suboxydans upon erythritol. J. Amer. chem. Soc. 60, 2507. 
Williams, A. E., Keppie, J. \& Smith, H. (1962). The chemical basis of the virulence of Brucella abortus. III. Foetal erythritol a cause of the localization of Brucella abortus in pregnant cows. Brit. J. exp. Path. 43, 530.

ZoBell, C. E. \& MeYer, K. F. (1932). Metabolism studies on the Brucella group. IX. Physicochemical requirements in synthetic mediums. J. infect. Dis. 51, 361. 